\title{
HANDLING STRATEGIES AND MAPPING OF PEOPLE WITH SOCIAL WELFARE PROBLEMS (PMKS): A STUDY IN PAMEKASAN REGENCY
}

\author{
${ }^{*}$ Rofiaty, Rofiaty \\ University of Brawijaya, Malang
}

\begin{tabular}{|c|c|}
\hline ARTICLE DETAILS & \multirow{6}{*}{$\begin{array}{l}\text { ABSTRACT } \\
\text { The research aims to analyze the strategy of handling people with } \\
\text { social welfare problems (Penyandang Masalah Kesejahteraan } \\
\text { Sosial/ PMKS) in Pamekasan Regency. Further, this study also } \\
\text { aims to determine the most appropriate strategy in handling PMKS } \\
\text { and determine the priority scale in PMKS policy making in } \\
\text { Pamekasan regency. The foundation to determine the PMKS } \\
\text { handling strategy is derived from the mapping outcome as } \\
\text { reflected from its indicators which show a number of major socia } \\
\text { welfare problems that emerge in the region based on important } \\
\text { scale. The strategy of handling social welfare problems is explored } \\
\text { based on the root of the problem such as the emergence of } \\
\text { abandoned child problems as triggered by the lack of job vacancy } \\
\text { in Pamekasan Regency. The low employment rate is due to } \\
\text { environmental conditions with limited resources in Pamekasan } \\
\text { Regency. The PMKS handling strategies are through: increasing } \\
\text { the awareness and responsibilities of parents on the obligations of } \\
\text { their children for not neglecting their children, creating new jobs for } \\
\text { abandoned children in various business fields, intensively } \\
\text { providing counseling and social communication services to al } \\
\text { levels of society to prevent more victims of drugs, raising funds } \\
\text { associated with poverty alleviation, raising CSR funds from banks, } \\
\text { cooperatives and others to care for people with social welfare } \\
\text { problem, providing training and entrepreneurship skills, supporting } \\
\text { the creation of a scavenger positive image as friendly and honest } \\
\text { part of the society instead of thief, giving spiritual and mental } \\
\text { guidance, providing CD4 testing program, as well as intensively } \\
\text { providing counseling and social communication services to al } \\
\text { levels of society about this problem. }\end{array}$} \\
\hline & \\
\hline $\begin{array}{l}\text { JIAE (Journal Indonesian } \\
\text { Applied Economic) }\end{array}$ & \\
\hline $\begin{array}{l}\text { Keywords } \\
\text { handling strategy, mapping, } \\
\text { penyandang masalah } \\
\text { kesejahteraan sosial (PMKS) }\end{array}$ & \\
\hline Corresponding Author & \\
\hline Email: rofiaty@ub.ac.id & \\
\hline
\end{tabular}




\section{INTRODUCTION}

Planning a region development is about various fields including economic, politic and social, as well as the provision of facilities and infrastructure to support the successfulness of regional development in general and in Pamekasan Regency in particular. In line with the effort to achieve the development success, the indicator of the development successfulness should be reflected from education, income, and health matters. It requires several efforts and appropriate strategies for achieving development goals successfully in accordance with the mission and vision of Pamekasan Regency which is pronounced as "The realization of advanced Pamekasan, prosperous, competitive and sustainable agri-politan and Minneapolitan towards Allah bless".

Each region in its development implementation always strives to implement the program by reaching all fields fairly, equitably and continuously. Given in the era of Regional Autonomy, each region both City and Regency, is not only demanded to success but also independence, so that it will support the realization of local governments are advanced and highly competitive. The success and independence of regional development covering the economic field such as in the field of handling social welfare problems/ Penyandang Masalah Kesejahteraan Sosial (PMKS). Efforts to achieve the success of the development is the implementation of one of the activities that are the priority scale that must be implemented immediately is the mapping and strategy of handling social welfare issues, considering the results of these activities will be guidelines, the right direction and clear according to the environmental conditions in the area. Development of social welfare is an integral part of national development, also take an active role in improving the quality of life of the Indonesian nation (Sudarso, 2012). Without this activity, it will be difficult to determine which activities should take precedence, and which ones may be temporarily suspended in the handling of PMKS due to limited resources, especially time, cost and labor. The situation of social welfare in Indonesia can be seen in the Human Development Index (HDI). In 2007, Indonesia's HDI ranked 107 among 177 countries of the world. Compared with the index in the ASEAN neighboring countries, it shows that Indonesian's standard of living was above
Laos (130), Cambodia (131) and Myanmar (132). However, while this position was far below Singapore (25), Brunei Darussalam (30), Malaysia (63), Thailand (78), and the Philippines (80), this ranking was also surpassed by Vietnam (105), which ranked 109 in 2006 (UNDP, 2007; Suharto, 2009a). The $\mathrm{HDI}$ is a composite index that measures the average achievements in a country in three basic dimensions of human development: economic (a decent standard of living indicated by gross domestic product/GDP per capita in Purchasing Power Parity US dollars/PPP US\$); health (a long and healthy life measured by life expectancy at birth); and education (access to knowledge examined by adult literacy and combined gross enrolment in primary, secondary and tertiary level education) respectively (UNDP, 2007). Entering the year 2010, the Indonesian people are still faced with poverty, neglect, disability, social and behavioral disabilities, remoteness, disaster victims and violence, both primary and nonsocial impacts, which are not yet fully covered by the welfare development process Social (Sudarso, 2012). The result of this activity is expected to get "root of problem" in handling of PMKS.

To achieve competitive Pamekasan Regency, it needs to accomplish development success first both through achieving qualified human resource and providing required facilities and infrastructures. One of the focuses to achieve qualified human resource development is done through improving social welfare so that it will be able to reduce the number of people with social welfare problems (PMKS). This activity starts from the implementation of PMKS identification in all districts in Pamekasan Regency. The identification involves 26 PMKS indicators cited from the Regulation of the Social Minister No. 8 of 2012.

Bahri (2015) examined the PMKS handling strategy through communication strategy. The result shows that communication strategy through counseling that were done in four times for one year is not yet an effective strategy because it still needs to be further explored again through further research; thus, it becomes a pivotal point to conduct this research. The purpose of this research is to analyze the handling strategy for people with social welfare problems in Pamekasan Regency. In addition, this study also aims to determine the best suit strategy in handling 


\section{Handling Strategies and Mapping Of People with Social Welfare Problems (PMKS): A Study in Pamekasan Regency}

PMKS and determine the priority scale in PMKS policy making in Pamekasan regency.

\section{LITERATURATE REVIEW Mapping}

Mapping is the clustering of a set of areas that relate to several geographical locations of the region that include highlands, mountains, resources, and potential populations affecting socio cultural that have special characteristics in appropriate scale use (Soekidjo, 2004).

In the preparation of a map, the first step that needs to be done is the process of mapping is the stage of the stage that must be done in the design of a map. According to Intan Permanasari (2007), explains three stages of the mapping process that must be done: (1) Data collection phase, (2) Data presentation phase and (3) PMKS mapping phase.

\section{Strategy}

Each region is very important in dealing with PMKS, as this is one of the benchmarks of regional success in the implementation of its development. For that we need the right strategy target. The strategies of each region should be tailored to the problems in the area. It is also necessary to determine the priority scale in the strategy of handling because of the limited resources available.

Strategy is the plan of a series of maneuvers, covering all visible and invisible elements, to ensure success in achieving goals. According to Fred R. David (2008: 5) defines Strategic Management as an art and knowledge in formulating, implementing, and evaluating cross-functional decisions that enable an organization to achieve its goals. Hunger and Wheelen (2003) divide the strategic management process into four steps or four basic elements of environmental scanning, strategy formulation, strategy implementation, and evaluation and control.

\section{Millennium Development Goals (MDGs)}

This Declaration is an agreement of members of the United Nations (UN) on a package of global development directions that are formulated in several objectives: (1) Tackling Poverty and Hunger, (2) Achieving Basic Education for all, (3) Encouraging Gender Equality, and Women's Empowerment, (4) Reduce Child Mortality Rate, (5) Improving Maternal Health, (6) Fighting HIV / AIDs, Malaria and Other Diseases, and (7) Ensure Environmental Sustainability, and Establish a Global Partnership for Development.

\section{Strategy for Handling People with Social Welfare Problems (PMKS) \\ The strategy is related to the local} government policy as stated in the decision of the regional head (the like), and the involvement of the Local Government Work Unit (SKPD) to bridge, provide solutions to PMKS. In addition, it embraces all elements of society, youth organizations and other organizations to care and engage both directly and indirectly to address the problems of PMKS.

One example of a handling strategy that can be done especially by the government is to prepare a rehabilitation facility that houses street children, abandoned, homeless and beggars who are under the auspices and responsibilities of the Social Service; Involving various related agencies and establish cooperation with various parties for handling the problem of PMKS. Another handling strategy is that private institutions, together with the government and the community, help to deal with people with disabilities by organizing institutions or training places for them to provide jobs so that they can live independently (Christiani, 2013)

Another solution of PMKS handling is to provide guidance and counseling for PMKS, find solutions/facilitate/create jobs by engaging business people to participate in handling.

\section{People with Social Welfare Problems (PMKS) Definition}

People with social welfare problems (PMKS) are individuals, families or groups who, due to an obstacle, difficulty or disruption, cannot fulfill their social functions, so that they cannot adequately fulfill their life (physical, spiritual and social) needs; Such barriers can be poverty, neglect, disability, social impairment, underdevelopment, alienation and environmental changes (suddenly) that are less supportive of a disaster occurrence (Regulation of the Social Minister No. 8 of 2012).

\section{Basic Problems of PMKS}

There are many types of social welfare problems. The following will be presented five types of barriers that are the basis of the problem of people with social welfare problems are: (1) Economic dependency, (2) Inability to adjust, (3) Poor health, (4) Lacking or absence of leisure and recreational facilities, and (5) Social conditions, the provision and management of social services that are less good or not good. As for the types of PMKS based on the Regulation of the Minister of Social Affairs of the Republic of Indonesia Number 08 of 2012, there are 26 types, with the 
definition and criteria of Social Welfare Problems (PMKS), as follows: (1) Neglected toddlers, (2) Neglected children, (3) Children in conflicted with the law, (4) Street children, (5) Children with disabilities (ADK), (6) Children who are victims of violence or mistakenly treated, (7) Children with the need of special protection, (8) Abandoned elderly, (9) People with disabilities, (10) Prostitution, (11) Vagrants, (12) Beggar, (13) Scavenger, (14) Minority groups, (15) Former citizens of prison facilities (BWBLP), (16) People with HIV / AIDS (ODHA), (17) Drug abuse victims, (18) Trafficking victims, (19) Victims of violence, (20) Migrant workers with social problems (PMBS), (21) Natural disaster victims, (22) Social disaster victims, (23) Socially vulnerable women, (24) The poor, (25) Family with psychosocial problems, and (26) Remote indigenous communities.

\section{Potential and Sources of Social Welfare (PSKS)}

It is the potential and the resources available to humans, nature and social institutions that can be used for social welfare efforts. Types of PSKS include: (1) Social Workers of the Community, (2) Social Organization, (3) Karang Taruna, (4) Wahana Kesejahteraan, (5) The Business World undertaking UKS, (6) Pioneer and Heroism.

\section{EMPIRICAL STUDY}

Dempsey et. al (2011) in a study entitled The Social Dimension of Sustainable Development: Defining Urban Social Sustainability described urban development strategies through physical and non-physical factors. Non-physical factors include: education and training. Social justice: social, interpersonal and intra-generational, participation and social democracy, health, quality of life and well-being, social inclusion (social erection, social capital, community, safety, mixed tenure, fair distribution of income, Social networks, social cohesion, community cohesion, social networks, social interaction, sense of community and belonging, employment, residential stability (vs turnover), active community organizations and cultural traditions. The predominantly physical factors include urbanity, attractive public realm, decent housing, local environmental quality and amenity, accessibility (e.g. to local services and facilities/green space), sustainable urban design, neighborhood, and walkable neighborhood: pedestrian friendly. Both factors can be used as a basis in determining the PMKS handling strategy in the research.

Suharto (2009) found that there is a need to have the paradigm shift in the development of social welfare. While the system should be responsive to the dynamic and more complex social problems, the approaches need to celebrate the principles of human rights, democratization, and the role of civil society both in the formulation and in the implementation of social programs. This paradigm shift encompasses six broad themes:

a. The result of development should benefit all people.

In the past, the results of development benefited only a small portion of community which caused socio-economic gap. Now, we need to reform the process of development to make it more poor people-oriented by providing chances to people with social problems to get an access to development resources, including easy access to capital, social services and sustainable social protection schemes.

b. The strategies of development need to considers human being as subject of development.

The development paradigm that positions human beings as subjects of development will position the people with social problems as active players in activities meant for them and gives proper appreciation to their potentials and resources.

c. The approaches of development need to reflect on local potentials and culture.

the empowerment of people with social problems should be implemented by digging out, maintaining and developing social resources, including local wisdom. Socio-cultural values, such as social solidarity, cooperation, and trust should be optimized as basic resource in creating social responsibility.

d. Basic social services are provided for all citizens.

Accessibility to basic social services should be open to all people (universal approach), including people with social problem who so far have been marginalized.

e. Empowerment of people with social problems become joint-commitment between the central government and local government. 


\section{Handling Strategies and Mapping Of People with Social Welfare Problems (PMKS): A Study in Pamekasan Regency}

The relationship between central and local government is no longer structural but functional. Local governments need to have strong political will in designing and implementing social welfare programs for their citizens.

f. Empowerment of people with social problems is done on individual, family, group and community basis, and in an integrated way.

Empowerment of people with social problems should not be done by group approach only, but also by individual, family, group and community approach. The facilities to be provided should also be in various forms in accordance with the potentials and needs of people with social problems, including access to financial assistance.

According to Christiani (2013), PMKS handling strategy found in Semarang City are as follows:

Table 1

PMKS Handling Strategies in Semarang City

\begin{tabular}{|c|c|c|c|}
\hline $\begin{array}{l}\mathbf{N} \\
\mathbf{0} .\end{array}$ & $\begin{array}{l}\text { PMKS } \\
\text { Types }\end{array}$ & $\begin{array}{l}\text { Forms of } \\
\text { Activities }\end{array}$ & $\begin{array}{l}\text { Indicator of } \\
\text { success }\end{array}$ \\
\hline 1. & $\begin{array}{l}\text { The } \\
\text { poor }\end{array}$ & $\begin{array}{ll}\text { - } & \text { Food aid } \\
\text { Establish } \\
\text { ment of } \\
\text { Joint } \\
\text { Business } \\
\text { Groups } \\
\text { - Housing } \\
\text { assistan } \\
\text { ce } \\
\text { - Educatio } \\
\mathrm{n} \\
\text { assistan } \\
\text { ce and } \\
\text { skills } \\
\text { upgradin } \\
\text { g } \\
\text { Business } \\
\text { capital } \\
\text { assistan } \\
\text { ce; } \\
\text { Setup } \\
\text { back to } \\
\text { home } \\
\text { area }\end{array}$ & 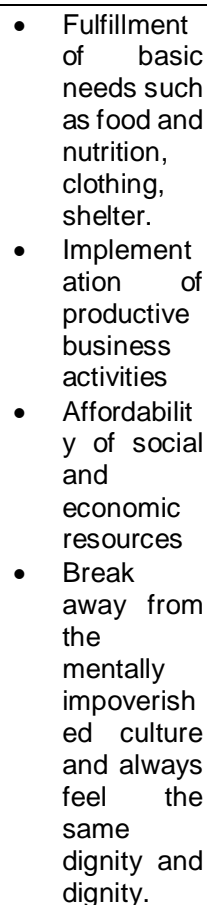 \\
\hline 2. & $\begin{array}{l}\text { Neglect } \\
\text { ed } \\
\text { Toddler }\end{array}$ & $\begin{array}{ll}- & \text { Reunific } \\
\text { ation of } \\
\text { abandon } \\
\text { ed } \\
\text { babies } \\
\text { Baby } \\
\text { and } \\
\text { Environ } \\
\text { mental } \\
\text { Health }\end{array}$ & $\begin{array}{l}\text { - Increased } \\
\text { number of } \\
\text { neglected } \\
\text { toddlers to } \\
\text { obtain } \\
\text { essential } \\
\text { needs } \\
\text { services, } \\
\text { Increased } \\
\text { accessibilit } \\
y \quad \text { of }\end{array}$ \\
\hline
\end{tabular}

\begin{tabular}{|c|c|}
\hline $\begin{array}{ll} & \text { Assistan } \\
& \text { ce } \\
\text { - } & \text { Family } \\
\text { Counseli } \\
\text { ng } \\
\text { - Administ } \\
\text { ration } \\
\text { Services }\end{array}$ & 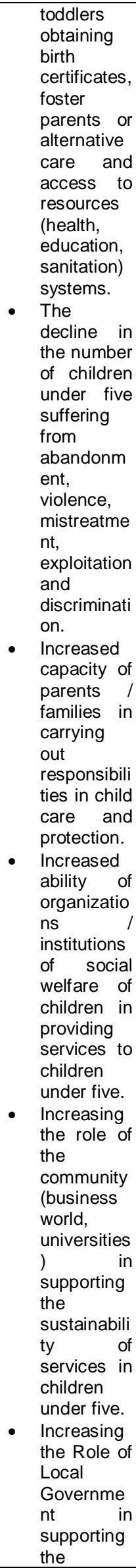 \\
\hline
\end{tabular}




\begin{tabular}{|c|c|c|c|}
\hline & & & $\begin{array}{l}\text { success of } \\
\text { providing } \\
\text { services to } \\
\text { children } \\
\text { under five. }\end{array}$ \\
\hline 3. & $\begin{array}{l}\text { Neglect } \\
\text { ed } \\
\text { Children }\end{array}$ & $\begin{array}{ll}-\quad \text { Group } \\
\text { Coachin } \\
\text { g } \\
\text { - } \quad \text { Formatio } \\
\mathrm{n} \text { of } \\
\text { Forum / } \\
\text { Containe } \\
\mathrm{r} \\
\text { - } \quad \text { Place of } \\
\text { Activities } \\
\text { Establish } \\
\text { ment of } \\
\text { Informati } \\
\text { on } \\
\text { Center } \\
\text { Mental } \\
\text { Guidanc } \\
\text { e } \\
\text { Family } \\
\text { Guidanc } \\
\text { e }\end{array}$ & 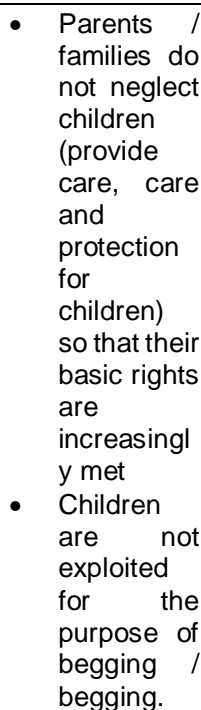 \\
\hline 4 & $\begin{array}{l}\text { Abando } \\
\text { ned } \\
\text { Elderly }\end{array}$ & $\begin{array}{ll}\text { - } & \text { Social } \\
\text { Services } \\
\text { in the } \\
\text { orphana } \\
\text { ge } \\
\text { - } \quad \text { Out-of- } \\
\text { home } \\
\text { Social } \\
\text { Services } \\
\text { - Social } \\
\text { Services } \\
\text { Protectio } \\
\text { n and } \\
\text { Accessib } \\
\text { ility } \\
\text { Institutio } \\
\text { nal } \\
\text { Social } \\
\text { Services }\end{array}$ & $\begin{array}{ll}\text { - } & \begin{array}{l}\text { Abandone } \\
\text { d elderly }\end{array} \\
\text { - } & \text { Home } \\
\text { - } & \text { Safe } \\
\text { shelter } \\
\text { - } & \text { Potentially } \\
\text { neglected } \\
\text { elderly } \\
\text { people can } \\
\text { take care } \\
\text { of and } \\
\text { support } \\
\text { themselve } \\
\text { s } \\
\text { own }\end{array}$ \\
\hline 5 & $\begin{array}{l}\text { Vagrant } \\
\mathrm{s} \text { and } \\
\text { Beggar }\end{array}$ & $\begin{array}{ll}- & \text { House } \\
- & \text { Lipases } \\
- & \text { Transit } \\
& \text { home } \\
\text { - } & \text { Settleme } \\
& \text { nt } \\
\text { - } & \text { Transmi } \\
& \text { gration }\end{array}$ & 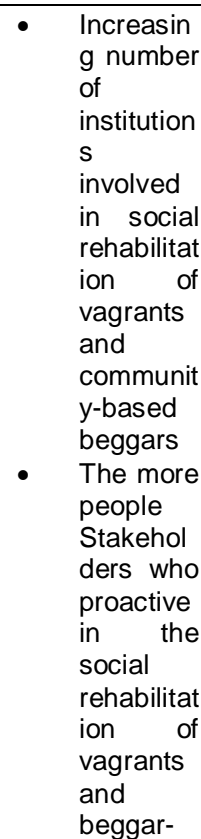 \\
\hline
\end{tabular}

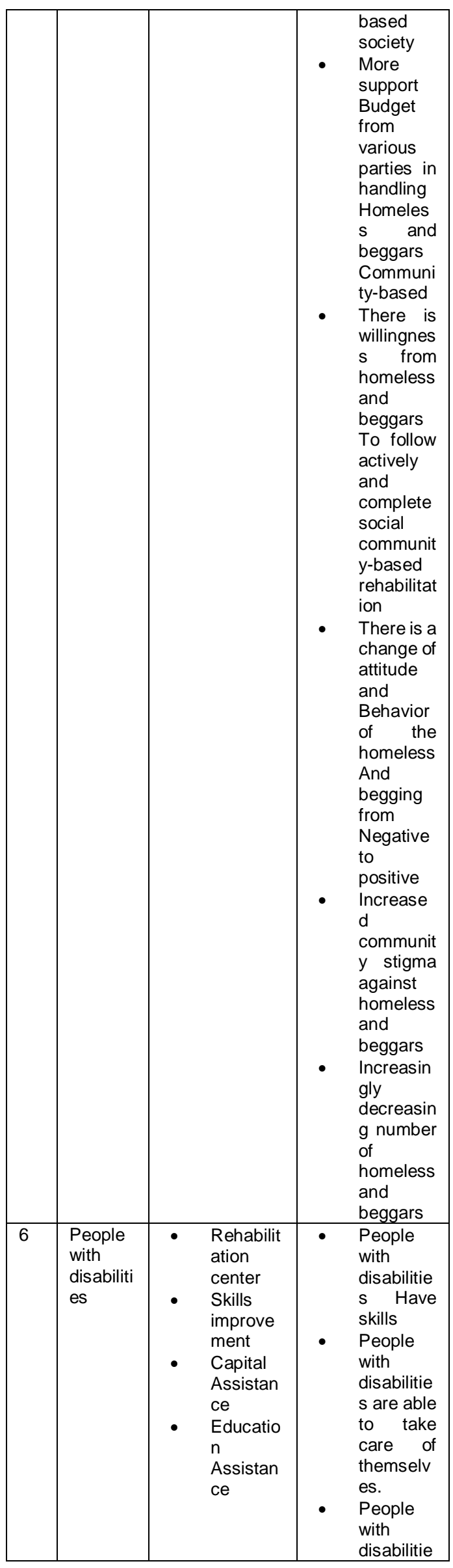




\section{Handling Strategies and Mapping Of People with Social Welfare Problems (PMKS): A Study in Pamekasan Regency}

\begin{tabular}{|c|c|c|c|}
\hline & & $\begin{array}{ll}\text { - } & \text { Giving } \\
\text { field } \\
\text { work }\end{array}$ & $\begin{array}{l}\text { s can } \\
\text { nourish } \\
\text { themselv } \\
\text { es }\end{array}$ \\
\hline 7 & $\begin{array}{l}\text { Street } \\
\text { Children }\end{array}$ & $\begin{array}{ll}\text { - } & \text { Establish } \\
\text { ment of a } \\
\text { Children' } \\
\text { s Center } \\
\text { Include } \\
\text { Street } \\
\text { Children } \\
\text { to } \\
\text { Educatio } \\
\text { nal } \\
\text { Institutio } \\
\text { ns } \\
\text { Increasin } \\
\text { g Family } \\
\text { Income } \\
\text { of Street } \\
\text { Children } \\
\text { Quality } \\
\text { Improve } \\
\text { ment } \\
\text { Protectio } \\
\text { n and } \\
\text { Care } \\
\text { Street } \\
\text { children }\end{array}$ & $\begin{array}{l}\text { - Parents / } \\
\text { families } \\
\text { do not } \\
\text { abandon } \\
\text { s the } \\
\text { child } \\
\text { (Providin } \\
\text { g care, } \\
\text { Parenting } \\
\text { and } \\
\text { protectio } \\
\text { n for } \\
\text { children) } \\
\text { so that } \\
\text { their } \\
\text { basic } \\
\text { rights are } \\
\text { increasin } \\
\text { gly met } \\
\text { Children } \\
\text { are not } \\
\text { exploited } \\
\text { for the } \\
\text { purpose } \\
\text { of } \\
\text { begging / } \\
\text { begging } \\
\text { Street } \\
\text { children } \\
\text { no longer } \\
\text { Doing } \\
\text { economic } \\
\text { activities } \\
\text { on the } \\
\text { streets, } \\
\text { returning } \\
\text { to school } \\
\text { children, } \\
\text { returning } \\
\text { to } \\
\text { families } \\
\text { (for } \\
\text { separate } \\
\text { d } \\
\text { children), } \\
\text { Follow } \\
\text { the } \\
\text { activity } \\
\text { Increase } \\
\text { d self- } \\
\text { potential / } \\
\text { Skills } \\
\text { The } \\
\text { abandon } \\
\text { ed child is } \\
\text { in parent / } \\
\text { family } \\
\text { care or } \\
\text { alternativ } \\
\text { e care }\end{array}$ \\
\hline
\end{tabular}

\section{RESEARCH METHOD}

The type of this research is an applied research. The analysis technique uses two type of approaches including qualitative descriptive approach to determine handling strategy and quantitative approach to map and determine the priority scale in PMKS policy making in Pamekasan regency. The data collection is done through identifying the emergence of PMKS in several villages of each sub-district in Pamekasan Regency. 
FINDINGS

Problem of PMKS in Pamekasan Regency

Table 2

Problem Comparison and Problem in PMKS Handling at Pamekasan Regency in 2015

\begin{tabular}{|l|l|l|l|l|}
\hline NO & Type of Problem & $\begin{array}{l}\text { Number } \\
\text { of } \\
\text { Problem }\end{array}$ & $\begin{array}{l}\text { Number } \\
\text { Conducted } \\
\text { Handling }\end{array}$ & Percentage (\%) \\
\hline 1 & Neglected toddlers (1) & 1,120 & 13 & 1.16 \\
\hline 2 & Neglected children (2) & 14,379 & 1,372 & 9.5 \\
\hline 3 & Children with The Need of Special Protection (7) & 55 & 0 & 0 \\
\hline 4 & Abandoned elderly (8) & 7,370 & 821 & 11 \\
\hline 5 & People with disabilities (9) & 1,271 & 60 & 4.7 \\
\hline 6 & Prostitution (10) & 12 & 0 & 0 \\
\hline 7 & Beggar (12) & 130 & 0 & 0 \\
\hline 8 & Scavengers (13) & 167 & 0 & 0 \\
\hline 9 & Former Citizens of Prison Facilities (BWBLP) (15) & 77 & 0 & 0 \\
\hline 10 & People with HIV / AIDS (16) & 30 & 30 & 100 \\
\hline 11 & Drug abuse victims (17) & 153 & 0 & 0 \\
\hline 12 & Victims of violence (19) & 61 & 0 & 0 \\
\hline 13 & $\begin{array}{l}\text { Migrant workers with social problems (PMBS) } \\
\text { (20) }\end{array}$ & 403 & 0 & 0 \\
\hline 14 & Natural disaster victims (21) & 1,274 & 110 & 8.6 \\
\hline 15 & Socially vulnerable women (23) & 7,106 & 120 & 1.7 \\
\hline 16 & The poor (24) & 85,878 & 1,631 & 1.9 \\
\hline 17 & Family with psychosocial problems (25) & 1,426 & 0 & 0 \\
\hline 18 & Remote indigenous communities (26) & 1 & 0 & 0 \\
\hline Source: Primary data, data proceed, 2016 & & 0 & \\
\hline
\end{tabular}

The foundation to determine the PMKS handling strategy is derived from the mapping outcome as reflected from its indicators which show a number of major social welfare problems that emerge in the region based on important scale. The strategy of handling social welfare problems is explored based on the root of the problem such as the emergence of abandoned child problems as triggered by the lack of job vacancy in Pamekasan Regency. The low employment rate is due to environmental conditions with limited resources in Pamekasan Regency. 


\title{
Handling Strategies and Mapping Of People with Social Welfare Problems (PMKS): A Study in Pamekasan Regency
}

\author{
The Mapping of PMKS Problem in \\ Pamekasan Regency
}

Table 3

PMKS Problem Rank in 2015 at Pamekasan

Regency

\begin{tabular}{|c|c|c|c|c|c|c|c|c|c|c|c|c|c|c|c|c|c|c|c|c|c|}
\hline No & $\begin{array}{l}\text { Sub- } \\
\text { district }\end{array}$ & 1 & 2 & 7 & 8 & 9 & $\begin{array}{l}1 \\
0\end{array}$ & 12 & $\begin{array}{l}1 \\
3\end{array}$ & $\begin{array}{l}1 \\
5\end{array}$ & $\begin{array}{l}1 \\
6\end{array}$ & $\begin{array}{l}1 \\
7\end{array}$ & $\begin{array}{l}1 \\
9\end{array}$ & $\begin{array}{l}2 \\
0\end{array}$ & $\begin{array}{l}2 \\
1\end{array}$ & $\begin{array}{l}2 \\
3\end{array}$ & $\begin{array}{l}2 \\
4\end{array}$ & $\begin{array}{l}2 \\
5\end{array}$ & $\begin{array}{l}2 \\
6\end{array}$ & $\begin{array}{l}\text { Number } \\
\text { s of } \\
\text { Proble } \\
\text { ms }\end{array}$ & Rank \\
\hline 1 & Tlanakan & $\checkmark$ & - & $\checkmark$ & - & - & - & $\checkmark \quad-$ & - & - & - & - & - & $\checkmark$ & $\checkmark$ & $\checkmark$ & - & $\checkmark$ & - & 7 & 2 \\
\hline 2 & Pamekasan & - & $\checkmark$ & - & $\checkmark$ & $\checkmark$ & - & - & $\checkmark$ & $\checkmark$ & $\checkmark$ & - & - & - & $\checkmark$ & $\checkmark$ & - & - & - & 8 & 1 \\
\hline 3 & Galis & - & - & - & - & $\checkmark$ & $\checkmark$ & - & - & - & - & - & - & - & $\checkmark$ & - & - & - & - & 3 & 5 \\
\hline 4 & Larangan & - & - & - & - & $\checkmark$ & - & - & $\checkmark$ & - & - & - & - & - & - & - & - & - & - & 2 & 6 \\
\hline 5 & Pademawu & $\checkmark$ & & - & - & $\checkmark$ & - & - & $\checkmark$ & - & $\checkmark$ & - & - & - & - & - & - & - & - & 4 & 4 \\
\hline 6 & Proppo & - & - & - & - & - & - & - & $\checkmark$ & - & - & - & - & - & - & - & $\checkmark$ & $\checkmark$ & - & 3 & 5 \\
\hline 7 & Palengaan & - & - & - & $\checkmark$ & $\checkmark$ & - & - & $\checkmark$ & - & - & $\checkmark$ & $\checkmark$ & - & - & $\checkmark$ & $\checkmark$ & - & - & 7 & 2 \\
\hline 8 & Pegantenan & - & $\checkmark$ & - & $\checkmark$ & - & - & - & $\checkmark$ & - & $\checkmark$ & - & - & - & - & $\checkmark$ & - & - & - & 5 & 3 \\
\hline 9 & Kadur & - & - & - & - & - & - & - & - & - & - & - & - & - & - & - & $\checkmark$ & - & - & 1 & 7 \\
\hline 10 & Pakong & - & $\checkmark$ & - & $\checkmark$ & - & - & - & - & - & - & - & - & - & - & $\checkmark$ & - & - & - & 3 & 5 \\
\hline 11 & Waru & $\checkmark$ & $\checkmark$ & - & - & - & - & - & - & $\checkmark$ & - & - & - & - & - & $\checkmark$ & $\checkmark$ & - & - & 5 & 3 \\
\hline 12 & Batumarmar & - & - & - & $\checkmark$ & - & - & - & - & - & - & - & - & - & - & - & - & - & - & 1 & 7 \\
\hline 13 & Pasean & - & - & - & $\checkmark$ & - & - & - & - & $\checkmark$ & - & - & - & - & - & - & - & $\checkmark$ & $\checkmark$ & 4 & 4 \\
\hline
\end{tabular}

Source: Primary data, data proceed, 2016.

Pamekasan sub-district ranks $1^{\text {st }}$ as reflected in yellow marking and has 8 priority problems, including neglected child (2), neglected elderly (8), people with disabilities (9), scavenger (13), former citizens of prison facilities (BWBLP) (15), people with HIV / AIDS (16), natural disaster victims (21), socially vulnerable women (23).

Tlanakan and Palengaan sub-districts are ranked second (2nd) in green markings and have 7 problems, including neglected toddlers (1), children needing special protection (7), beggars (12), migrant workers with social problems (20), victims of natural disasters (21), socially vulnerable women (23), families with psychosocial problems (25). While the problems of the District of Palengaan are, neglected elderly (8), persons with disabilities (9), scavengers (13), drug abuse victims (17), victims of violence (19), socially vulnerable women (23), and the poor (24).

Pegantenan sub-district and Waru subdistrict are ranked third (3rd) in pink markings and have 5 problems, including neglected children (2), neglected elderly (8), scavengers (13), people with HIV / AIDS (ODHA) (16), socially vulnerable women (23). The problems of Waru sub-district include neglected children (1), neglected children (2), former citizens of prison facilities (BWBLP) (15), socially vulnerable women (23), and the poor people (24).
Pademawu and Pasean sub-districts are ranked fourth (4th) in blue markings and have 4 problems, including neglected toddlers (1), persons with disabilities (9), scavengers (13), people with HIV / AIDS (ODHA)) (16). The problems of Pasean sub-district include neglected elderly (8), former citizens of prison facilities (BWBLP) (15), families with psychosocial problems families (25), and remote indigenous communities (26). 


\section{Figure 1}

\section{People with Social Welfare Problems (PMKS) Mapping in Pamekasan Regency}

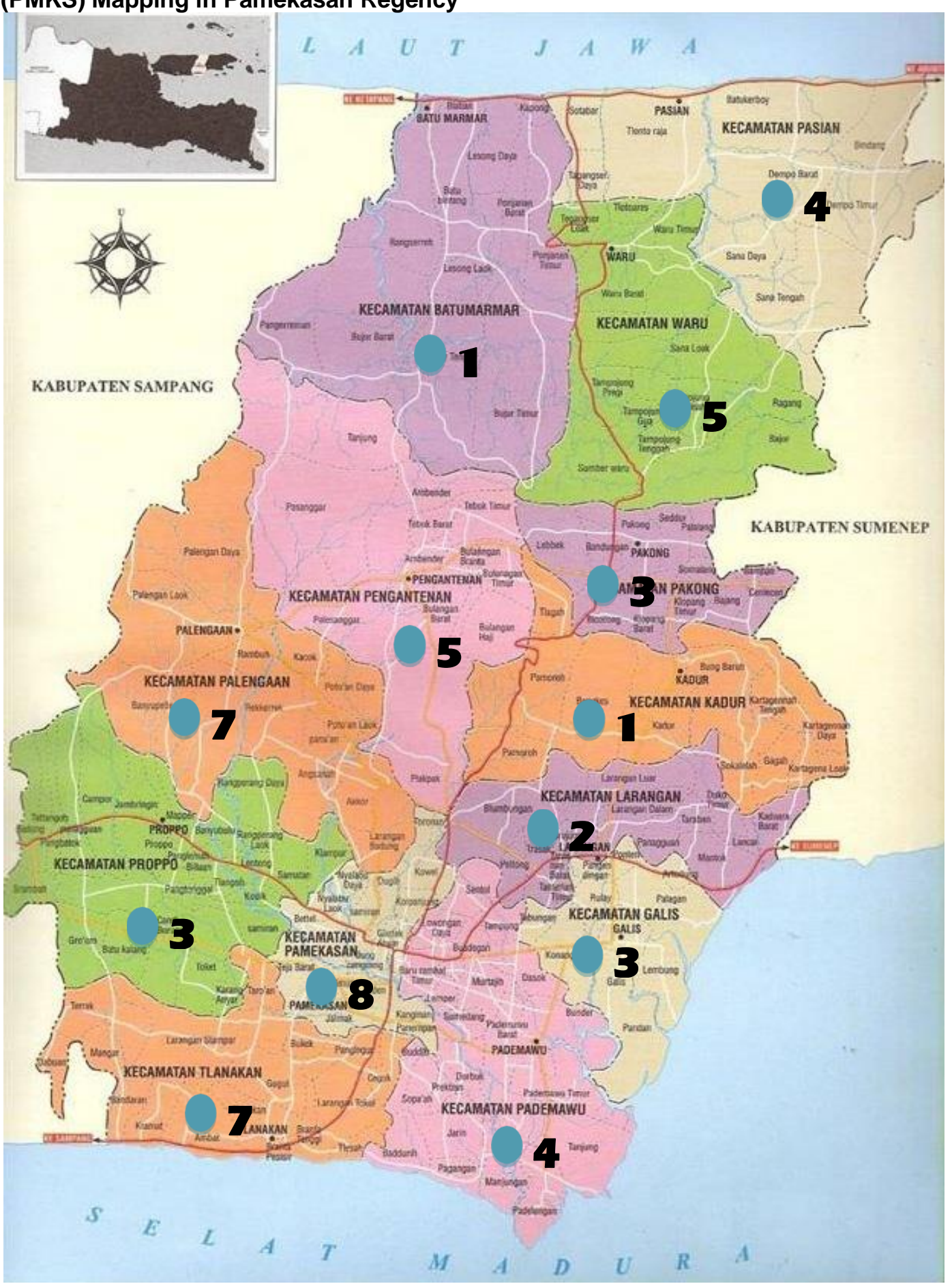

Note:

Round blue markings $($ with the highest figure indicating the districts with the biggest problems of

Based on Table 3 and Figure 1 above, it can be described that the sub-district which has the most problems (8) is considered to have the highest ranking (1st) and vice versa, the lowest ranking with the least number of problems (1), more detail information is described below: 


\section{Handling Strategies and Mapping Of People with Social Welfare Problems (PMKS): A Study in Pamekasan Regency}

1. Pamekasan sub-district with the highest number of problems (8) portrayed in blue round marking $(8)$ is ranked in first.

2. Tlanakan and Palengaan sub-districts with 7 problems portrayed in blue round marking $(\odot 7)$ is ranked in second.

3. Waru sub-district with 5 problems portrayed in blue round marking $(\odot 5)$ is ranked in third.

4. Pademawu, Pegantenan and Pasean subdistricts with 4 problems portrayed in blue round marking (4) is ranked in fourth.

5. Galis, Proppo and Pakong sub-districts with 3 problems is portrayed in blue round marking $(-3)$ is ranked in fifth.

6. Larangan sub-district with 2 problems is portrayed in blue round marking ( $\odot 2)$ is ranked in sixth.

7. Kadur and Batumarmar with one problem portrayed in blue round marking $(\odot 1)$ is ranked in seventh.

\section{Neglected Toddler (1)} children (pr

The average number of neglected

1) in Pamekasan Regency is 86 children. Based on the average number, problem 1 (neglected toddlers) that occurs beyond the average happens in the following districts: Pademawu sub-district consists of 390 people, Tlanakan sub-district consists of 270 people, and Waru sub-district consists of 93 people. Problem handling that had been done is handling only 13 children or $1.16 \%$. While the handling strategies that have been done so far are:

a. Helping children who are abandoned by parents by sending them to a government orphanage center in Sidoarjo (one baby).

b. Police Resort of Pamekasan helped to make a deal with a toddler who is abandoned by his parents and sent him to an orphanage.

c. The health office provided milk and snacks supply as an effort to improve the nutrition of abandoned toddlers.

The recommended handling strategies that should be done are as follows:

1. Increasing the awareness and responsibilities of parents on the obligations of their children for not neglecting them.

2. Local governments need to create new jobs for vulnerable parents who have neglected toddlers in order to have economic capability.

3. Continuing to distribute the abandoned children to related institutions like public orphanage in Sidoarjo if there is a similar case.

4. Making effective empowerment and involvement of related institutions in handling abandoned children/ toddler problem.

\section{Neglected Children (2)}

The average number of abandoned child problems ( $p r$ 2) in Pamekasan Regency is 1,106 children. Based on the average number, problem 2 (abandoned toddlers) that occurs beyond the average happens in the following districts: Waru sub-district consists of 3,067 people, Pamekasan sub-district consists of 2,435 people, Pakong sub-district consists of 1,458 people, and Pegantenan sub-district consists of 1,214 people. Problem handling that had been done looking after 1,373 children or $9.5 \%$. The handling strategy that has been done is like providing entrepreneurship training and supporting tools that encourage new business startup in several fields such as workshop, sewing, and make-up. This effort is expected to be able to open new business in those fields. Those children were previously interviewed before getting relevant training based on their interests and talents. The handling strategy that should be done are as follows:

1. Creating new jobs for abandoned children in various business fields by growing and improving entrepreneurial spirit in accordance with the potential of Pamekasan Regency including Fishery, Agriculture, Animal husbandry, Workshop, Tailor, Cosmetics (Make Up), Catering, Trading, etc.

2. Inviting private companies (Honda, Suzuki, Auto 2000), SOEs and Local GovernmentOwned Enterprise (BUMD) to conduct relevant trainings and workshops.

\section{Children with The Need of Special Protection (7)}

The average number of children who need special protection ( pr 7) in Pamekasan Regency is 55 children. The only district that has this problem is Tlanakan; yet, there is no problem handling that has been conducted in Tlanakan Sub-district until now. The handling strategy that should be done are as follow:

1. Intensively providing counseling and social communication service to all levels of society to prevent more victims of drugs.

2. Intensively carrying out raids in places that are prone to child exploitation and sexual violence (such as bus station, markets, entertainment venues, etc.). 
3. Intensively carrying out the raids to the places that sell liquor and enforcing the rules firmly associated with this matters.

\section{Abandoned Elderly (8)}

The average number of abandoned elderly ( $\mathrm{pr}$ 8) problems in Pamekasan Regency is 566 people. Problem handling that had been done is for this problem looked after 821 people or $11 \%$. Based on the average number, problem 8 (neglected elderly) that occurs beyond the average happens in the following districts: Pamekasan sub-district consists of 895 people, Pegantenan sub-district consists of 887 people, Palengaan sub-district consists of 873 people, Pakong sub-district consists of 729 people, Batumarmar sub-district consists of 668 people and Pasean 617 sub-district consists of people. While the handling strategy that has been done are as follow:

a. Providing home construction assistance for 2 residents whose condition is very apprehensive.

b. Providing food aid from the social ministry.

c. Provision of sleeping equipment aid.

The handling strategy that should be done are as follows:

1. Funds associated with poverty alleviation should also be allocated to these people.

2. Raising CSR funds from banks, cooperatives and others to care for people with this problem by allocating the funds of CSR.

\section{People with Disabilities (9)}

The average number of disability problems (pr 9) in Pamekasan Regency is 97 people. Problem handling that had been done so far included as many as 60 people or $4.7 \%$. Based on the average number, problem 9 (disabled people) that occurs beyond the average happens in the following districts: Galis subdistrict consists of 199 people, Larangan subdistrict consists of 146 people, Pademawu subdistrict consists of 140 people, Pemekasan subdistrict consists of 139 people, and Palengaan sub-district consists of 122 people.

While the handling strategy that has been done by Social Service Institution in cooperation with inter-religions forum of East Java facilitates people with disabilities to get artificial hands and feet. The recommended strategy that should be done is to allocate some funds from interreligions forum, ZIS institution, and various government institutions for people with disabilities by providing training for them to achieve productive competencies and skills.

\section{Prostitution (10)}

The average problem of prostitutes ( $p r 10)$ in Pamekasan Regency is 12 people. The subdistrict that experiences this problem is Galis sub-district; yet, there is no problem handling at all. The handling strategy that should be done are as follows:

1. Providing training and entrepreneurship skills to be able to engage in society by conducting various economic activities in accordance with their talent and ability.

2. Informing through religious or healthrelated counseling that the prostitute action is immoral and against any religion rule

3. Eradicating the places of prostitution as well as enforcing strict regulations that result in deterrent effect.

4. Improving the quality of religious faith and obedience (IMTAQ) to the God Almighty.

\section{Beggar (12)}

The average case occurrence of beggar (pr 12) problem in Pamekasan Regency is 130 people. The sub-district that faces this problem is Tlanakan sub-district; yet, there is no problem handling at all. The problem handling strategy that should be done is to intensify the implementation of counseling to increase the awareness of the beggar community about human dignity to be willing to work hard and feel embarrassed to be beggars from scholars and public figures. Further, they should also internalize and implement the values that practiced by the holy prophet.

\section{Scavengers (13)}

The average occurrence of scavenger problems (pr 13) in Pamekasan Regency is 12 people. Based on the average number, problem 13 (scavengers) that occurs beyond the average happens in the following districts: Pemekasan sub-district consists of 22 people, Larangan sub-district consists of 22 people, Pademawu sub-district consists of 20 people, Proppo sub-district consists of 19 people, Pegantenan sub-district consists of 17 people, and Palengaan sub-district consists of 16 people. Pamekasan, Larangan, Pademawu, Proppo, Pegantenan and Palengaan subdistricts has not yet conducted problem handing effort until. The handling strategy that should be done are as follows:

1. Supporting to build a positive image of scavenger as friendly and honest for preventing miss-perception of the society as scavenger is often perceived as a thief.

2. If possible, the local government should provide assistance to the scavenger group in the form of waste treatment facility like 


\section{Handling Strategies and Mapping Of People with Social Welfare Problems (PMKS): A Study in Pamekasan Regency}

paper and plastic wastes processing machine to be processed into recycled products.

3. Providing training on how to process products that have more economic added value than recycled products.

\section{Former Citizens of Prison Facilities (BWBLP) (15)}

The average occurrence of former prisoners (pr 15) problem in Pamekasan Regency is 11 people. Based on the average number, problem 15 (former citizens built institutions prisoner) that occurs beyond the average happens in the following districts: Pasean sub-district consists of 24 people, Waru sub-district consists of 17 people, and Pamekasan sub-district consists of 16 people. There is no treatment or problem handling in these three sub-districts so far. The handling strategy that should be done is:

1. Spiritual and mental guidance to prevent them to be a bully in the community and shame to commit a crime so that it will not eventually make them become inmates of prison again.

2. Providing training in order to make them have a productive business so that they will not have any intention to commit a crime again.

3. Providing skills training in any field of business so that they are not clumsy to blend with the community which eventually will make them become the part of a productive society.

People with HIV / AIDS (ODHA) (16)

The average occurrence of people with HIV / AIDS (prison) problems (pr 16) in Pamekasan Regency is 3 people. Based on the average number, problem 16 (People with HIV/ AIDS) that occurs beyond the average happens in the following districts: Pamekasan sub-district consists of 7 people, Pegantenan sub-district consists of 6 people and Pademawu sub-district consists of 4 people. Problem handling that had been done looked after 30 people or $100 \%$. While the handling strategy that had been done so far are as follows:

a. Free testing and free counseling for people with HIV / AIDS.

b. Free regular medical treatment.

c. Free CD4 checking for revealing immune antibodies with HIV / AIDS per six months or per year depending on the patient's condition.

The handling strategy that should be done are as follows:

Faculty of Economics and Business, Brawijaya University
1. It is recommended to continue the existing program like free test, medication and CD4 testing program.

2. Providing counseling to the public to avoid free sex behavior and other behaviors that is contagious the HIV / AIDS.

\section{Drug Abuse Victims (17)}

The average occurrence of drug abuse victim (pr 17) in Pamekasan Regency is 152 people. The Pakong sub-district which experiences this problem has not yet conducted any problem handling until now.

The handling strategies that should be done are as follow:

1. Intensively providing counseling and social communication service to all levels of society for not repeating the behavior of drugs abuse.

2. Intensively carrying out raids to places that provide narcotics, psychotropic substances and other legally forbidden additives.

3. Providing action explicitly and legal sanctions for drug dealers and users to cause deterrent effect.

\section{Victims of Violence (19)}

The average occurrence of victims of violence (pr 19) in Pamekasan Regency is 30 people. The sub-districts that face this problem are Palengaan and Pasean sub-districts; yet, there is no problem handling treatment at all and until now. The handling strategy that should be done are:

1. Avoiding direct contact with person or parties who often do violence.

2. Being more careful in public places, and not dress up conspicuously (wearing excessive jewelry and wearing clothes that seem to attract sexual arousal).

3. Backing up yourself and belongings (installing alarm, CCTV, double lock).

Socially problematic migrant worker (PMBS) (20)

The average occurrence of problematic migrant worker problem (pr 20) in Pamekasan Regency is 100 people. Yet Tlanakan subdistrict has beyond average number of which reaches 274 people. Tlanakan Sub-district until now has not yet handled this problem. The handling strategy that should be done is to provide skills training in any field of business so that they are not clumsy to the community, and they become part of a productive society.

Victims of natural disasters (21)

The average occurrence of disaster victims (pr 21) in Pamekasan Regency is 159 people. 
Based on the average number, problem 21 (victims of natural disasters) that occurs beyond the average happens in the following districts: Tlanakan sub-district consists of 415 people, Pamekasan sub-district consists of 203 people and Galis sub-district consists of 162 people. Problem handling has been done for 110 people or $8.6 \%$. While the handling strategy that had been done are providing cash aid and providing food directly to the victim. The handling strategies that should be done are:

1. Implementing fund raising movement for the natural disaster victims considering the occurrence of natural disasters are uncertain.

2. Implementing identification and evaluation of conditions prone to natural disasters, such as the existence of old trees alongside roads that are vulnerable to tumbles, as well as roads and areas prone to landslides.

\section{Socially vulnerable women (23)}

The average occurrence of problems of socioeconomic vulnerable women (pr 23) in Pamekasan Regency is 546 people. Based on the average number, problem 23 (women vulnerable to social economy) that occurs beyond the average happens in the following districts: Pamekasan sub-district consists of 1,394 people, Pagantenan sub-district consists of 759 people, Waru sub-district consists of 756 people, Palengaan sub-district consists of 707 people, Tlanakan sub-district consists of 680 people, and Pakong sub-district consists of 628 people. Problem handling has been done for 120 people or $17 \%$ of the population. While the strategy of handling that had been done is to provide livestock grant. The handling strategy that should be done are:

1. For population in productive age, they should take business opportunities from the surrounding environment at a scale that they can manage. This will be strengthened by a high entrepreneurial spirit.

2. Leave the unproductive lifestyle and alter to more productive activities to attain income.

\section{The Poor (24)}

The average occurrence of the problem of the poor (pr 24) in Pamekasan Regency is 6,606 people. Based on the average number, problem 24 (the poor) that occurs beyond the average happens in the following districts: Proppo subdistrict consists of 12,103 people, Tlanakan sub-district consists of 10,062 people, Palengaan sub-district consists of 9,831 people and Kadur sub-district consists of 8,624 people. Problem handling had been done for 1,631 people or merely $1.9 \%$ of the population. While the handling strategy that had been done were:

a. The fund assistance of home renovation with a budget of 10 million rupiah

b. Air compressor assistance.

c. Hair-do equipment assistance that can support them to become entrepreneurs in the field of makeup, which at the same time it can create jobs.

d. Facilitate the children of the poor to obtain assistance in education and living expenses through governmentadministered orphanages.

The handling strategy that should be done are as follows:

1. Providing assistance in the form of activity creation as a livelihood (income center). This can be achieved when there is a new investment or business that can absorb the workforce from the poor people.

2. Creating new jobs that accommodate the poor by connecting the industry from upstream to downstream in order to have more added value so that they can get a higher wage rate in order to meet the basic needs that are appropriate for the needs of themselves and their families.

\section{Family with Psychosocial Problems (25)}

The average occurrence of family with psychological social problem (pr 25) in Pamekasan Regency is 238 people. Based on the average number, problem 25 (family with psychosocial problem) that occurs beyond the average happens in the following districts: Proppo sub-district which consists of 404 people and Tlanakan sub-district which consists of 295 people. Proppo and Tlanakan subdistricts had not yet conducted any treatment for this problem. The handling strategy that should be done are as follows:

1. Mental development and enhancement of the devotion of married couples to be more committed to their obligations. This is in line with the realization of the vision and mission achievement of Pamekasan Regency to Gerbang Salam.

2. Improving the relationship through silaturrahim with surrounding neighbors so as tō build cooperation among members of the community, such as the formation of piggy bank groups (arisan) in holy quran recital and family empowerment program $(P K K)$. This activity will help them to meet the needs of children both physically and spiritually. 


\section{Handling Strategies and Mapping Of People with Social Welfare Problems (PMKS): A Study in Pamekasan Regency}

3. Increase the logical and mature thinking of husband and wife to be always grateful for whatever is conferred on them so that will create a sakinah mawaddah warohmah (peaceful, happy and happy world hereafter) family.

Remote Indigenous Communities (26)

The average occurrence of the remote indigenous communities ( $\mathrm{pr} 26$ ) problem in Pamekasan Regency is 1 person. Pasean subdistrict is the only sub-district that faces this problem but not yet take action to handle the occurring problem. The strategy handling that should be done are:

1. Increasing awareness of the community and religion in accordance with the applicable norms in accordance with the 1945 Constitution which is full of tolerance.

2. The Government should pay attention to the existence of these remote indigenous groups by engaging in dialogue to accommodate their needs though the government itself has limitations and constraints.

\section{CONCLUSION}

1. The largest number of problems in each sub-district of Pamekasan Regency is the huge number of the poor people. The strategy taken by Local Government through related institutions should be more focused on handling the problems of the poor. It can be through engineering technology in the field of agribusiness to increase soil fertility, encourage new entrepreneurs, more job creation for people with limited formal education.

2. The number of neglected children is the second largest number that must be prioritized to be handled strategically. The handling strategy that can be done like:

a. Providing non formal education

b. Distributing those abandoned children in public school as their affirmative students.

3. The number of socio-economic vulnerable women occupies a sizable number of PMKS in Pamekasan Regency. The handling strategy to do may include:

a. Fostering mental, moral, and religious aspect of society.

b. Developing the knowledge and skills of the women resources by providing assistance for entrepreneurship even on a micro scale.

4. The highest PMKS handling in Pamekasan Regency based on its sub-districts is presented below:

Faculty of Economics and Business, Brawijaya University
1. Batumarmar sub-district handles $73 \%$

2. Pademawu sub-district handles $70 \%$

3. Pasean sub-district handles $68 \%$

4. While the lowest handling is in Proppo sub-district which handles only $11 \%$.

\section{IMPLICATION}

1. This research can be used as a reference for further research in handling PMKS, though it should be adapted to the recent situation in other areas

2. There is a need of conducting an indepth analysis based on the root of the problem that occur in the handled area so that it can reflect a situation analysis through observing both internal and external environment.

\section{RECOMMENDATION}

1. It needs a commitment of local government in handling the problems continuously in order to solve the existing PMKS issues.

2. Local Government needs to intensively propose plans of activities at the central government which its output can provide solutions and reduce the PMKS problems in the region of Pamekasan Regency.

3. It needs to increase the amount of funds in various assistance in handling PMKS issues.

\section{GLOSSARY}

PMKS: Penyandang Masalah Kesejahteraan Sosial/People with Social Welfare Problems

CD4: T cells that have CD4 proteins. It works as a respirator for HIV

\section{REFERENCES}

Badan Perencanaan Pembangunan Daerah Kabupaten Pamekasan, 2015. Profil Kabupaten Pamekasan 2015, Badan Perencanaan Pembangunan Daerah Kabupaten Pamekasan.

Bahri, Samsul. 2015. Strategi Komunikasi Dinas Kesejateraan Sosial Dalam Menangani Penyandang Masalah Kesejahteraan Sosial (PMKS) Di Kota Samarinda. Journal Universitas Mulawarman : Samarinda.

Christiani, Charis. 2013. Strategi Penyelenggaraan Kesejahteraan Sosial Masyarakat Kota Semarang. (https://jurnal.untagsmg.ac.id/index.php/ sa/article/view/60). Diakses Juni. 
Dempsey, Nicola, Bramley, Glen, Power, Sinead, Caroline Brown. 2011. The Social Dimension of Sustainable Development: Defining Urban Social Sustainability. Oxford Brookes University : United Kingdom.

Fred R. David. 2008. Manajemen Strateg : Konsepdan Studi Kasus. Jakarta.

Hunger, J. David., and Thomas L. Wheelen. 2003. "Manajemen Strategis", edisi II, Diterjemahkan oleh: JuliantoAgung, Penerbit ANDI Yogyakarta.

John A. Pearce II dan Richard B.Robinson, Jr. 2008. Manajemen Strategis. Formulasi, Implementasi dan Pengendalian. Jakarta: Salemba Empa.

Malhotra. 2005. Riset Penelitian. Jakarta: Gramedia Pustaka Utama

Netting, F. Ellen, Peter M. Kettner dan Steven L. McMurtry. 1993. Social Work Macro Practice. New York: Longman.

---- (2002). Profiles and Dynamics of the Urban Informal Sector in Bandung: A Study of Pedagang Kaki lima, unpublished PhD thesis. Palmerston North: Massey University

Peraturan Menteri Sosial RI No. 08 Tahun 2012.Pedoman Pendataan dan Pengelolaan Data Penyandang Masalah Kesejahteraan Sosial dan Potensi dan Sumber Kesejahteraan Sosial.

Singarimbun, Masri dan Sofian Effendi. 2008. Metode Penelitian Survei. Jakarta: LP3ES

Soekidjo.2004. Pengembangan Potensi Wilayah.Bandung :Gramedia.

Stalker, Peter. 2008. Millennium Development Goals. UNDP : Indonesia

Sudarso, 2012, Identifikasi dan Strategi Penanganan PMKS Studi Kasus di Kabupaten Pasuruan.(http://sudarsosbyfisip.web.unair.ac.id/artikel detail68026-Umuml-

DENTIFIKASI\%20DAN\%20STRATEGI $\% 20 \% 20$ PENANGANAN\%20PMKS\%20 STUDI\%20KASUS\%20DI\%20KABUPAT EN\%20PASURUAN.html). Diakses Juni 2017.

Suharto, Edi. 2006. Membangun Masyarakat Memberdayakan Rakyat: Kajian Strategis Pembangunan Kesejahteraan Sosial dan Pekerjaan Sosial (Building Community Empowering People: Strategic Analysis on Social Welfare Development and Social Work). Bandung: Refika Aditama (second edition)

Suharto, Edi. 2009. Kemiskinan dan Perlindungan Sosial (Poverty and Social Protection). Bandung: Alfabeta
Sugiyono, 2009. Metode Penelitian Bisnis. Bandung : Alfabeta

Suharto, Edi. 1997. Pembangunan, Kebijakan Sosial dan Pekerjaan Sosial: Spektrum Pemikiran. Bandung: Lembaga Studi Pembangunan STKS (LSP-STKS).

Suharto, Edi. 2014. Metode dan Teknik Pemetaan Sosial : Jurnal

Suharto, Edi. 2009. Development of Social Welfare in Indonesia. National Institute of Public Administration: Jakarta.

UNDP (United Nations Development Pogramme). 2007. Human Development Report 2007/2008 Fighting Climate Change : Human Solidarity in a Divided World. New York: UNDP.

Twelvetrees, A. 1991. Community Work, London: McMillan.

Warren, R. L. 1978. The Community in America. Chicago: Rand McNally. 